\title{
The Influence of Learning Maturity, Self-confidence, Learning Facilities, and Achievement on Students' Interest to be A Teacher
}

\author{
Selviani' ${ }^{1}$ Idris ${ }^{2}$, Marwan $^{3}$ \\ ${ }^{1}$ Faculty of Economics, Universitas Negeri Padang, Padang, Indonesia \\ $\triangle$ (e-mail) selvianiazhar428@gmail.com \\ ${ }^{2}$ Dept. of Economics, Faculty of Economics, Universitas Negeri Padang, Padang, Indonesia \\ $\triangle$ (e-mail) idris_unp@yahoo.co.id \\ ${ }^{3}$ Dept. of Economics Education, Faculty of Economics, Universitas Negeri Padang, Padang, Indonesia \\ $\square($ e-mail) marwan@fe.unp.ac.id
}

\begin{abstract}
The aim of this research is to show the influence of learning maturity, self-confidence, learning facilities, and achievement on the students' interest to be a teacher. The research is a descriptive and associative research. The population in this research are 216 students in senior high school in city of Tembilahan, Indragili Hilir. A total of 140 students were chosen as research sample using random sampling technique. A set of questionnaire was distributed to the students, after which some tests were done to verify the validity and reliability. To analyze the data, path analysis and hypothesis tests were used. The findings show that learning maturity, self-confidence, learning facilities, and achievement have a positive impact on the students' interest to be economic teachers.
\end{abstract}

Keywords: learning maturity, self-confidence, learning facilities, achievement, and students' interest to be economic teachers

\section{Introduction}

Syah (2005:180) defined the interest is the high tendency and desire for something. Basically, the interest in is the acceptance to the relationship between external and internal conditions ourselves. If that relationship is stronger, than the interest in is bigger. The interest in to be a teacher is the internal factor pushing and affecting someone's behavior that feels interesting in and actualizing to be a teacher.

In the past, to be a teacher was considered as an uninteresting profession. However, to be a teacher is now become one of the interesting profession because getting a certification program by government to increase the life's welfare. Besides they got a base salary and an allowance, as the civil servant, they got a reward or are named the certification program.

In fact, the students have a low interest in to the educational world, particularly in the Department of Economic Education. The number of new students in Department of Economic Education, Universitas Negeri Padang (UNP) through direct admission (invitation) which are shown on the following Table 1.

Table 1 The number of new students in Department of Economic Education, UNP through direct admission

\begin{tabular}{llll}
\hline No & Years & Candidate & Percentage (\%) \\
\hline 1 & 2013 & 1.121 & 52 \\
\hline 2 & 2014 & 783 & 36 \\
\hline 3 & 2015 & 688 & 32 \\
\hline 4 & 2016 & 671 & 31 \\
\hline Total & & 2.143 &
\end{tabular}


Table 2 shows the number of new students in Department of Economic Education, Universitas Negeri Padang (UNP) through admission test. The data in both Table 1 and 2 show the low students' interest to join the Department of Economic Education, UNP is fluctuated every year.

Table 2 The number of new students Department of Economic Education, UNP

through admission test

\begin{tabular}{llll}
\hline No & Years & Students & Percentage (\%) \\
\hline 1 & 2013 & 24 & 12 \\
\hline 2 & 2014 & 42 & 21 \\
\hline 3 & 2015 & 52 & 26 \\
\hline 4 & 2016 & 43 & 21 \\
\hline \multicolumn{2}{l}{ Total } & 199 & \\
\hline \multicolumn{2}{c}{ Data source: Puskom UNP, 2018 }
\end{tabular}

There are some factors affecting students' interest to be a teacher. One of the factor is the achievement. Gore in Berry and Driel (2012) argued for a focus on pedagogy in teacher education such that pre-service teachers (PSTs) should "develop deep understanding of the complexities surrounding learning as well as strong skills for producing learning," to support their own students to "achieve high quality learning outcomes."

Meanwhile, factors affecting of the achievement is a learning maturity. Slameto (2013) explains that learning maturity is all of someone's condition which is making to already give the answer in a particular way for a situation. It is become one of the influence factors for the student achievement. If the students have a good learning maturity, then they will get a good achievement. As pointed out by Kaymak and Horzum (2013) that there is a positive relation among the learning maturity with the interaction and achievement.

The second factor affecting the achievement is a self-confidence. According to Hakim (2003: 6) the self confidence is someone's faith for all of the power that they have and that faith make them feeling like that reach what they want. In the learning process, the students must be independent in their study, so that students being active in saying their opinions. Furthermore, the passive students keep silent and hearing the teacher and it will be affecting the learning process and the student achievements. According to Shoemarker in his research is showing that measure of student achievement is selfconfidence.

Besides the learning maturity and self-confidence, the next affecting factor of the achievement is the learning facilities. Djamarah $(2006,46)$ explained the facilities are all of things which take easy to the students. The nice learning facilities can make the students comfortable and will get the good achievements. The facilities are the tools which used to increase learning process and to affect the student achievements as well. Schneider (2002) described the learning facilities affecting for the student achievement.

The research purposes will be describing the learning maturity, self-confidence, learning facilities impact for the achievements of social students of senior high school in Kota Tembilahan, Indragiri Hilir regency, Riau and will be describing the learning maturity, self-confidence, learning facilities impact for the interest in to be a teacher of social students of senior high school in city of Tembilahan, Indragiri Hilir regency, Riau. And then, the benefits of research that the research result will give input to develop the educational world and will be used as reference for further research.

\section{Methods}

This study is a quantitative descriptive research. The research population was 216 senior high school students in Humanuties major at Tembilahan. The sampling technique used was random sampling, resulted with 140 students. The research instrument used was a set of questionnaire. The data were analyzed using path analysis that use the SPSS program 16.00 for windows. In this research, learning 
maturity, self-confidence, and learning facilities are the exogenous variables. Meanwhile, the academic achievement is the intervening, and the interest in to be a teacher is the endogenous variable.

\section{Results and Discussion}

The research aims to examine the influence of the learning maturity, self-confidence, learning facilities, and achievement for the interest in to be a teacher that used the path analysis. For path analysis, the structure relation on a path diagram was divided. The first was the path coefficient of model I analysis and the second was the path coefficient of model II analysis. The path coefficient of model I analysis explained the variable impact of learning maturity $\left(X_{1}\right)$, self-confidence $\left(X_{2}\right)$, learning facilities $\left(X_{3}\right)$, student achievement $\left(X_{4}\right)$. Meanwhile, the path coefficient of model II analysis explained the impact of learning maturity $\left(X_{1}\right)$, self-confidence $\left(X_{2}\right)$, learning facilities $\left(X_{3}\right)$, on the interest in to be economic teachers $(\mathrm{Y})$.

Table 3 The influence of learning maturity $\left(X_{1}\right)$, self-confidence $\left(X_{2}\right)$, learning facilities $\left(X_{3}\right)$ on students' achievement $\left(X_{4}\right)$

\begin{tabular}{llllll}
\hline Variable & $\begin{array}{l}\text { Path } \\
\text { coefficient } \\
\text { (Beta) }\end{array}$ & $\begin{array}{l}\text { Value } \\
\text { Sig. }\end{array}$ & Test result & $\begin{array}{l}\text { Determine } \\
\text { coefficient }\end{array}$ & $\begin{array}{l}\text { Other } \\
\text { Variable } \\
\text { Coefficients }\end{array}$ \\
\cline { 1 - 4 } $\mathrm{X}_{1}$ to $\mathrm{X}_{4}$ & 0.208 & 0.007 & significant & 0.530 & \\
\cline { 1 - 4 } $\mathrm{X}_{2}$ to $\mathrm{X}_{4}$ & 0.365 & 0.000 & significant & $=$ & 0.6855 \\
\cline { 1 - 4 } $\mathrm{X}_{3}$ to $\mathrm{X}_{4}$ & 0.289 & 0.000 & significant & $53.0 \%$ & \\
\hline
\end{tabular}

Based on that value we've got a path diagram for the path coefficient of model I, which is seen on the following picture:

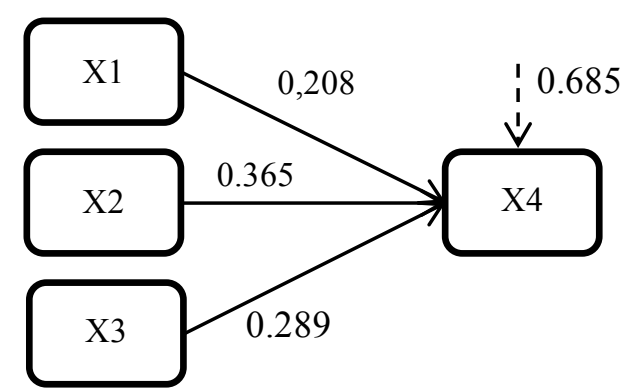

Figure 1 The influence of learning maturity $\left(X_{1}\right)$, self-confidence $\left(X_{2}\right)$, learning facilities $\left(X_{3}\right)$ on students' achievement $\left(\mathrm{X}_{4}\right)$

The structural equations for the path coefficient of model I, is as follow.

$$
\begin{aligned}
& Y=p y X 1+p y X 2+\varepsilon 1 \\
& Y=0.208+0.365+0.289+0.685 \\
& \text { where } \mathrm{R}^{2}=0.530
\end{aligned}
$$

The results of structural equations of the path coefficient of model I, show as follows. First, the student achievement $\left(X_{4}\right)$ is affected by the learning maturity $\left(X_{1}\right)$, the self-confidence $\left(X_{2}\right)$, the learning facilities $\left(\mathrm{X}_{3}\right)$ simultaneous and significant which is $53 \%$ and $47 \%$ is affected by another variable. Second, if the learning maturity $\left(X_{1}\right)$ is good, then the student achievement $\left(X_{4}\right)$ is good as well. Otherwise, if the learning maturity $\left(X_{1}\right)$ is bad, then the student achievement $\left(X_{4}\right)$ is bad as well. Third, if the students' self-confidence $\left(X_{2}\right)$ is good, then the student achievement $\left(X_{4}\right)$ is good as well. Otherwise, if the students' self-confidence $\left(X_{2}\right)$ is bad, then the student achievement $\left(X_{4}\right)$ is bad as well. Fourth, if the learning facilities $\left(X_{3}\right)$ are good, then the student achievement $\left(X_{4}\right)$ is good as well. Otherwise, if the learning facilities $\left(X_{3}\right)$ are bad, then the student achievement $\left(X_{4}\right)$ is bad as well. 
Table 4 The influence of learning maturity $\left(\mathrm{X}_{1}\right)$, self-confidence $\left(\mathrm{X}_{2}\right)$, learning facilities $\left(\mathrm{X}_{3}\right)$ on the interest in to be economic teachers $(\mathrm{Y})$

\begin{tabular}{llllll}
\hline Variable & $\begin{array}{l}\text { Path } \\
\text { coefficient } \\
\text { (Beta) }\end{array}$ & $\begin{array}{l}\text { Value } \\
\text { Sig. }\end{array}$ & Test result & $\begin{array}{l}\text { Determine } \\
\text { coefficient }\end{array}$ & $\begin{array}{l}\text { Other } \\
\text { Variable } \\
\text { Coefficients }\end{array}$ \\
\cline { 1 - 4 } $\mathrm{X}_{1}$ to $\mathrm{Y}$ & 0.359 & 0.000 & Significant & \multirow{2}{*}{0.644} & \\
\cline { 1 - 4 } $\mathrm{X}_{2}$ to $\mathrm{Y}$ & 0.197 & 0.007 & Significant & $=$ & 0.596 \\
\cline { 1 - 5 } $\mathrm{X}_{3}$ to $\mathrm{Y}$ & 0.189 & 0.007 & Significant & $64.4 \%$ & \\
\hline $\mathrm{X}_{4}$ to $\mathrm{Y}$ & 0.220 & 0.004 & Significant & & \\
\hline
\end{tabular}

Based on the values, the path diagram for path coefficient of model II is presented in Figure 2.

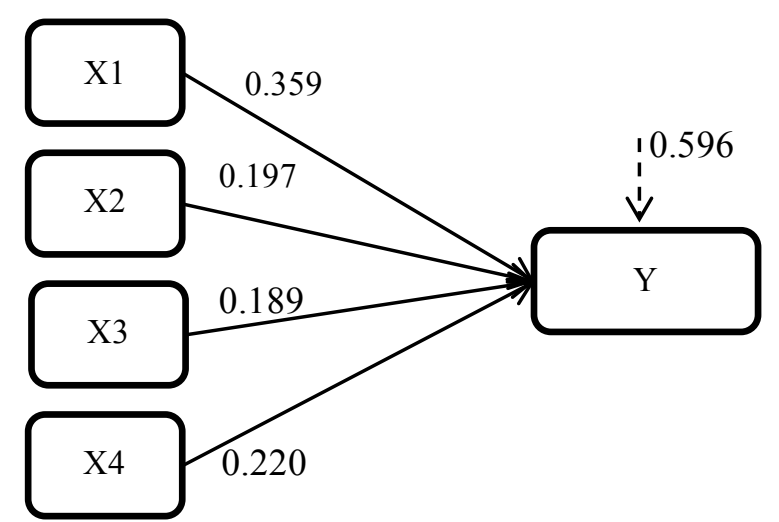

Figure 2 The influence of learning maturity $\left(X_{1}\right)$, self-confidence $\left(X_{2}\right)$, learning facilities $\left(X_{3}\right)$ on the interest in to be economic teachers $(\mathrm{Y})$

The structural equations for the path coefficient of model II, is as follows

$$
\begin{aligned}
& Y=p Y X 1+p Y X 2+p Y X 3+p Y X 4+\varepsilon 2 \\
& Y=0.359+0.197+0.189+0.220+0.596 \\
& \text { Where }^{2}=0.644
\end{aligned}
$$

The results of structural equations of the path coefficient of model II show that as follows. First, the interest in to be a teacher $(\mathrm{Y})$ is affected by the learning maturity $\left(\mathrm{X}_{1}\right)$, self-confidence $\left(\mathrm{X}_{2}\right)$, learning facilities $\left(\mathrm{X}_{3}\right)$ simultaneous and significant which is $64.4 \%$ and $36.6 \%$ is affected by another variable. Second, if the learning maturity $\left(\mathrm{X}_{1}\right)$ is good, then the interest in to be an economic teacher $(\mathrm{Y})$ is high as well. Otherwise, if the learning maturity $\left(\mathrm{X}_{1}\right)$ is bad, then the interest in to be an economic teacher $(\mathrm{Y})$ is low as well. Third, if the students' self-confidence $\left(\mathrm{X}_{2}\right)$ is good, then the interest in to be an economic teacher $(\mathrm{Y})$ is high as well. Otherwise, if the students' self-confidence $\left(\mathrm{X}_{2}\right)$ is bad, then the interest in to be an economic teacher $(\mathrm{Y})$ is low as well. Fourth, if the learning facilities $\left(\mathrm{X}_{3}\right)$ are good, then the interest in to be an economic teacher $(Y)$ is high as well. Otherwise, if the learning facilities $\left(X_{3}\right)$ are bad, then the interest in to be an economic teacher $(\mathrm{Y})$ is low as well. Fifth, if the student achievement $\left(\mathrm{X}_{4}\right)$ is good, then the interest in to be an economic teacher $(\mathrm{Y})$ is high as well. Otherwise, If the student achievement $\left(\mathrm{X}_{4}\right)$ is bad, then the interest in to be an economic teacher $(\mathrm{Y})$ is low as well.

\section{The learning maturity impact for the student achievements in economic lesson}

Based on the path analysis result that we've done before, we have gotten the direct coefficient value of the learning maturity for the student achievements in economic lesson (total impact) that is $20.8 \%$. The hypothesis test showing, the learning maturity has a positive and a significant impact for the student achievements in economic lesson to the social students of senior high school class XI, Tembilahan. That mean, when the students have a good learning maturity, then they will get a good achievement whereas when the students have a bad learning maturity, then they will get a bad achievement. 
The results are consistent with Muliyani (2013) who reports that learning maturity has related in the pretty strong correlation coefficient level between the student achievements and the learning maturity.

\section{The learning maturity impact for the interest in to be an economic teacher}

Based on the path analysis results, we have gotten the direct coefficient value of the learning maturity for the interest in to be a teacher that is $35.9 \%$. The hypothesis test showing, the learning maturity has a positive and a significant impact for the interest in to be a teacher in the social students of senior high school class XI, Tembilahan. That mean, when the students have a good learning maturity, then they will have the high interest in to be a teacher whereas when the students have a bad learning maturity, then they will have the low interest in to be a teacher.

The results are consistent with $\mathrm{Ni}^{\prime}$ mah (2014) who describes the students' interest to be teachers affected for the maturity to be a teacher and Slameto (2010:113) explained that "the maturity has the three aspects that is skill, knowledge, and understanding"

\section{The self-confident impact for the student achievements in economic lesson}

Based on the path analysis result that we've done before, we have gotten the direct coefficient values of the self-confident for the student achievements in economic lesson (total impact) that is $36.5 \%$. The hypothesis test showing, the self-confident has a positive and a significant impact for the student achievements in economic lesson to the social students of senior high school class XI, Tembilahan. That mean, when the students have a good self-confident, then they will get a good achievement whereas when the students have a bad self-confident, then they will get a bad achievement.

The results are consistent with Janiati et al. (2014) who explains there is a positive impact between the self-confident for the student achievements in economic lesson. From this result showing when the students have a good self-confident, then they will get a good achievement whereas when the students have a bad self-confident, then they will get a bad achievement. So, to the student begin to be brave to ask when follow learning activity in other to the student achievement will increase.

\section{The self-confident impact for the interest in to be an economic teacher}

Based on the path analysis result that we've done before, we have gotten the direct coefficient value of the self-confident for the interest in to be a teacher $19.7 \%$. The hypothesis test showing, the selfconfident has a positive and a significant impact for the interest in to be a teacher in the social students of senior high school class XI, Tembilahan. That mean, when the students have a good self-confident, then they will have the high interest in to be a teacher whereas when the students have a bad selfconfident, then they will have the low interest in to be a teacher.

The results are consistent with Hakim (2005) who explains self-confidence is someone's faith for all of the power that they have and that faith make them feeling like that reach what they want.

\section{The learning facilities impact for the student achievements in economic lesson}

Based on the path analysis result that we've done before, we have gotten the direct coefficient value of the learning facilities for the student achievements in economic lesson (total impact) that is $28.9 \%$. The hypothesis test showing, the learning facilities have a positive and a significant impact for the student achievements in economic lesson to the social students of senior high school class XI, Tembilahan. That mean, when the students have the good learning facilities, then they will get a good achievement whereas when the students have the bad learning facilities, then they will get a bad achievement.

The results are consistent with Bagun (2008) who explains that there is a positive and significant impact between the facilities impact for the student achievements in economic lesson. The results indicate that learning facilities is complete and worthy, it will help learning activities students, so will increase the student achievements. 


\section{The learning facilities impact for the interest in to be an economic teacher}

Based on the path analysis result that we've done before, we have gotten the direct coefficient value of the learning facilities for the interest in to be a teacher $18.7 \%$. The hypothesis test showing, the learning facilities have a positive and a significant impact for the interest in to be a teacher in the social students of senior high school class XI, Tembilahan. That mean, when the students have the good learning facilities, then they will have the high interest in to be an economic teacher whereas when the students have the bad learning facilities, then they will have the low interest in to be an economic teacher. Hurlock $(2010,117)$ explained that the interest in has a cognitive, emotion, and conation factors. Conation factor will get from learning process which is supported by the good learning facilities.

\section{The student achievements impact for the interest in to be an economic teacher}

Based on the path analysis result that we've done before, we have gotten the direct coefficient value of the student achievements for the interest in to be a teacher $18.7 \%$. The hypothesis test showing, the student achievements have a positive and a significant impact for the interest in to be a teacher in the social students of senior high school class XI, Tembilahan. That mean, when the students have the good achievement, then they will have the high interest in to be an economic teacher whereas when the students have the bad achievement, then they will have the low interest in to be an economic teacher. This result is matching in Diyantini et al. (2016) explained in them research result that student achievements have a positive and a significant impact for the interest in to be a teacher in the accounting education program FKIP UNS.

\section{Conclusions}

The aim of this research is to show the influence of learning maturity, self-confidence, learning facilities, and achievement on the students' interest to be a teacher. The research is a descriptive and associative research. The population in this research are 216 students in senior high school in city of Tembilahan, Indragili Hilir. A total of 140 students were chosen as research sample using random sampling technique. A set of questionnaire was distributed to the students, after which some tests were done to verify the validity and reliability. To analyze the data, path analysis and hypothesis tests were used.

The findings of this study show that learning maturity, self-confidence, learning facilities, and achievement have an impact for the interest in to be a teacher directly or indirectly. That means to increase the learning maturity and self-confidence, to pay attention the learning facilities in home or school, and to increase the achievement could increase the interest in to be an economic teacher so that could be maximizing their potency.

\section{Acknowledgments}

The authors would like to express their gratitude to SMA Negeri 1 Kota and SMA Negeri 1 Indragiri Hilir, Riau, for their participation in this research.

\section{References}

Bangun, Darwin. (2008). Hubungan persepsi siswa tentang perhatian orang tua, kelengkapan fasilitas belajar, dan penggunaan waktu belajar di rumah dengan prestasi belajar ekonomi. Jurnal Ekonomi dan Pendidikan, 5 (1).

Berry, Amanda \& Van Driel, Jan H. (2012). Teaching about Teaching Science: Aims, Strategies, and Backgrounds of Science Teacher Educators. SAGE.

Diyantini, Sigit-Santosa \& Octaria, Dini. (2016). Pengaruh prestasi belajar dan persepsi mahasiswa tentang kesejahteraan guru terhadap minat menjadi guru pada mahasiswa Prodi Pendidikan Akuntansi FKIP UNS. Jurnal Tata Arta, 2(2).

Gie, The Liang. (2002). Cara Belajar Yang Efisien. Yogyakarta: Gajah Mada University Press.

Hakim, T. (2002). Mengatasi Rasa Tidak Percaya Diri. Jakarta: Puspa Swara. 
Hurlock, Elizabeth. (2010). Perkembangan Anak Jilid 2. Meitasari Tjandrasa (Translator). Jakarta: Erlangga.

Jananti, Nooriza \& Tarmudji, Tarsis. (2014). Pengaruh kepercayaan diri, budaya lokal dan pendidikan agama terhadap hasil belajar mata pelajaran ekonomi siswa kelas XI IPS SMA Negeri 1 Demak tahun ajaran 2013/2014. Economic Education Analysis Journal.

Kaymak, Demir-Zeliha \& Mehmet, Baris-Horzum. (2013). Relationship Between Online Learning Readiness and Structure and Interaction of Online Learning Students. Edam.

Mulyani, Dessy. (2013). Hubungan kesiapan belajar siswa dengan prestasi belajar. Jurnal Ilmiah Konseling, (2) 1.

Ni'mah, Fahmi. (2014). Pengaruh minat profesi guru, locus of control internal, peran guru pamong, dan prestasi belajar terhadap kesiapan mahasiswa menjadi guru pada jurusan pendidikan ekonomi fakultas ekonomi universitas negeri semarang. Economic Education Analysis Journal, 3.

Muhibbin, Syah. (2012). Psikologi Belajar. Jakarta: Rajawali Pers

Schnaider, Mark. (2002). Do School Facilities Affect Academic Outcomes? ERIC.

Shoemaker, A-Candice. (2010). Student confidence as a measure of learning in an undergraduate principles of horticultural science course. Kansas State University.

Slameto. (2003). Belajar dan Faktor-faktor yang Mempengaruhinya. Jakarta: Rineka Cipta. 